\title{
The objectification of adulthood of persons with deeper and deep intellectual disability
}

\begin{abstract}
Dorota Prysak, The objectification of adulthood of persons with deeper and deep intellectual disability. Interdisciplinary Contexts of Special Pedagogy, no. 26, Poznań 2019. Pp. 237-254. Adam Mickiewicz University Press. ISSN 2300-391X. e-ISSN 2658-283X. DOI: https:// doi.org/10.14746/ikps.2019.26.11
\end{abstract}

The adulthood of persons with deeper and deep disability continues to be a challenge not only for specialists and parents or caretakers of the indicated group of persons, but also for us as a society. The objective of the article is the presentation of effects of activities experienced by adults with deeper and deep intellectual disability while inhabitants of a social nursing home. One of the main effects of the mentioned activity is objectification. In the discussed case, the objectification is the effect of lack of trust or limited trust in their potential, which can become a factor of manipulation.

The research material used in the present study constitutes personal experiences gained while working with persons with deeper and deep intellectual disability, their caretakers, parents and other specialists working with them, acquired through participation in diverse activities/ projects aimed at them. Free, narrative discussions as well as focused discussions were conducted with representatives of the indicated groups (save for persons with deep, and in certain cases, significant intellectual disability). The analysis of the research material was conducted according to the action research methodology. ${ }^{1}$

${ }^{1}$ I assume that "Action research is that type of cognition that causes searching for new information related to the experienced problem. It occurs already at the stage of the problem situation causing one to search for solutions across many available sources. This encourages the organisation of people around commonly identified problems (mostly local ones, experienced here and now), and cooperation in 
KEY WORDS: adulthood, person with deeper and deep intellectual disability, objectification, action research

\section{Action research}

The vantage point for the study is the trivial thesis, even though it still must be stated clearly: That persons with intellectual disability continue to be discriminated in Poland. In many areas of daily lives, they do not have the same conditions, possibilities or chances of development as persons developing correctly. Even though suitable legal provisions and rules exist, in practice these people are not treated equally with others.

The objective of the article is the presentation of effects of activities experienced by adults with deeper and deep intellectual disability, in most cases living at social nursing homes. One of the main effects of the mentioned activities is objectification. In the discussed case, objectification is the effect of simplified trust that may be a factor in manipulation. The study constitutes musings based upon the results of action research. ${ }^{2}$

their solution. This encourages bonds and increases mutual trust, and unifies the community doing the research and action, contributing to more democratic relations and mutual learning" - Maria Czerepaniak-Walczak, Badanie w działaniu w kształceniu i doskonaleniu nauczycieli, „Przegląd badań Edukacyjnych 2014, no. 2, p. 185.

2 Referring to action research as a researcher engaged in action, in this study I will use this form of narrative in the first person; quoted from: P. Reason, W.R. Torbert: Zwrot działaniowy. Ku transformacyjnej nauce społecznej, [in:] H. Cervinkova, B.D. Gołębniak (ed.) Badania w działaniu. Pedagogika i pedagogika zaangażowane, Wydawnictwo Naukowe Dolnośląskiej Szkoły Wyższej, Wrocław 2010, pp. 136-147; B.D. Gołębniak: Edukacyjne badania w działaniu - między akademicka legitymizacja a realizowanymi uproszczeniami, [in:] H. Cervinkova, B.D. Gołębniak (ed.) Edukacyjne badania w działaniu, Wydawnictwo Naukowe Scholar, Warszawa 2013, pp. 54-55.

Action research means studying the social situation of the researcher, with the aim of improving it, meaning, honing the quality of one's activity during its course. This research is systemic gathering of information on phenomena causing certain changes, with the researcher instigating and actively participating in the events. 


\section{The adulthood of persons with deeper and deep intellectual disability}

Persons with intellectual disability are frequently treated solely as a component of social policy, meaning, as a population suffering from mental disability that must only be provided with full care at every stage of the lives of the individuals. ${ }^{3}$ In political, social and economic lives, they want to be treated as social partners.

Persons with deeper intellectual disability require decidedly more aid and support. It must be stressed, however, that despite their disability, the majority of these is able to work on a much higher level than foreseen by stereotypical societal expectations. The most difficult situation is experienced by persons with deep intellectual disability, as they require not only aid, but care around the clock. Their lives always depend on another. Hence, society is responsible for these people, who are not able to function without any kind of support.

Irrespective of the level of intellectual disability, all persons experiencing it are able to develop, and function the better, the earlier they and their families are provided with suitable aid and support, such as: early development stimulation, suitable medical care, education adapted to their needs and diverse forms of activity, employment included. Studies on learning and motivation of persons with intellectual disability have shown that their development capacities were underrated. The systematic encouragement to development, a consequent system of requirements, leads to activation

\footnotetext{
Action research is done when the possibility is seen of changes for the better in a situation; one prepares the design for its improvement, implements it and watches what comes out of it all: Whether the improvement project brought about the expected results or not. If not, one can create a further one, correcting the shortcomings of the former, in order to reimplement it again"; I quote from: Tadeusz Pilch, Teresa Bauman, Zasady badań pedagogicznych, strategie ilościowe i jakościowe, Wydawnictwo Akademickie „Żak”, Warszawa 2010, p. 307.

${ }^{3}$ Conf. K. Mrugalska, Osoby z upośledzeniem umystowym, [in:] K. Mrugalska, Osoby upośledzone fizycznie lub umystowo, op. cit., p. 55.
} 
and development of the capacities of these people. Intellectual disability is not an illness that will pass if it is treated properly. Persons with deeper intellectual disability will never cease to be disabled, however, just like any other, they can develop and change according to their capacities. The perception and execution of the dynamic concept of reduced intellectual disability creates new, real chances of development and activation of the indicated group of people, their mastery of psycho-social functions that are useful for them and for the environment. ${ }^{4}$ This in turn creates for them chances at subjective treatment by other members of society during diverse activities.

\section{From action to objectification}

We influence others to a smaller or broader extent, for instance, the social group we are members of, but we also continue to submit to influence by it. We are members of diverse circles: family, social, societal and professional ones; we meet various people in the most diverse of situations, hence, we cannot avoid influencing others we are in contact with, and vice versa - we cannot avoid their influence on us. The sole presence of others, whom we need to take into account in some way, influences our choices, our behaviour. In many instances, we consider other alternatives ourselves. ${ }^{5}$

Participating in social life, we are constantly the object of influence that we either recognise or define in a certain way, or, perceiving it, we fail to understand its real objectives. Such activities may be referred to manipulation in particular. We are dealing with manipulation when we are not able to recognise the actual objectives of activity. Manipulation is a "certain mode of influence on the behaviour of others, one, the mechanism of which is to remain secret from the people being subjected to the influence, hence, not subject to

${ }^{4} \mathrm{H}$. Borzyszkowska: Upośledzenie - rewalidacja dzieci i młodzieży upośledzonych umysłowo, [in:] Encyklopedia pedagogiczna, ed. by W. Pomykało, Warszawa 1993, p. 885.

${ }^{5}$ A. Grzywa, Potega manipulacji, Wydawnictwo Czelej, Lublin 2012, p. 1. 
open and direct influence of their consciousness" ${ }^{6}$ Manipulation is influence or driving of others. Anyone being the subject of manipulation is in general not aware of their instrumentality. The thing is that manipulation generally aims at covert objectification of others. ${ }^{7}$

The basis for further considerations aimed at characterising manipulation is the assumption that it is a technique of influence, a type of social influence. This influence entails the sender, utilising their knowledge on the rules of peoples' behaviour, attempts to exert a specific kind of influence on a person or group of people in such a way so that they would not be aware of the fact that they are subjected to purposeful influence. ${ }^{8}$ Considered along these lines, manipulation strives to omit human consciousness in order to achieve a set objective. ${ }^{9}$ Objectives described by the manipulating party are visions of such conditions that they plan to achieve, irrespective of whether they apply to them or the person being manipulated. Referring back to definitions of manipulation functioning in object literature, it must be noted that we are dealing with such a mode of influence when:

“(...) the fundamental motive of the person utilising social manipulation is the maximisation of their own interests or the interests of a group or institution with which they identify"10; "(...) attempts made in course of manipulation always implement objectives outside of the scope of the person being their direct object. Manipulators always achieve their own objectives, or the objectives of their principals, their superiors". ${ }^{11}$

${ }^{6}$ Z. Ziembiński, Wychowanie a manipulacja, „Wykłady Inauguracyjne” no. 21, Wyd. Nauk. UAM, Poznań 1981, p. 6.

${ }^{7}$ W. Łukaszewski, Szanse rozwoju osobowości, Książka i Wiedza, Warszawa 1984, p. 483.

${ }^{8}$ Conf. C.W. Mills, Elita władzy, „Książka i Wiedza”, Warszawa 1961, p. 416.

${ }^{9}$ Conf. R. Nawrat, Czy można manipulować przechodniami na polskiej ulicy? Empiryczne badanie efektywności wybranych sekwencyjnych procedur zwiększania uległości, „Przegląd Psychologiczny” 1989, vol. XXXII, no. 1, p. 205.

10 D. Doliński, Inni ludzie w procesach motywacyjnych, [in:] Psychologia. Podręcznik akademicki, vol. 2, ed. by J. Strelau, GWP, Gdańsk 2000.

11 A. Lepa, Świat manipulacji, Wydawnictwo Tygodnika Katolickiego „Niedziela", Częstochowa 1994, p. 135. 
The research presented in this study shows that daily lives provide examples of such activity towards persons with intellectual disability, irrespective of whether these are actions of individuals or of the state. The subject of adulthood of persons with deeper and deep intellectual disability continues to be a difficult issue for many. Reality is very brutal; we consider persons with disabilities when we are promised financial aid for them. Such a perception may be related to the following quote:

"Is manipulation perhaps conditioned not as much on the instrumental treatment of people, but on objective treatment - meaning, in the sense that when it occurs, the objective of activity of the subject is the good of that person, however, implemented without consideration of their rights to make free decisions and to develop freely. In this concept, one can speak of manipulation in upbringing (both of youths as well as of society at large) when it is based on the behavioural concept of man, when a child or adult is controlled by so-called behavioural engineering... the system of prizes and punishments, acting on emotions instead of thoroughly informing and convincing". ${ }^{12}$ The quote indicates just how important our knowledge is - both in terms of individuals as well as the entire community. The indicated knowledge and, primarily, awareness in noticing threats, contributes to the objective handling of persons with deeper and deep intellectual disability. The lack of reflective thought, in turn, may support activities that objectify the mentioned persons.

The Dictionary of the Polish Language ${ }^{13}$ a defines objectification as "assigning abstract concepts real presence". We also have the term "to objectify" that primarily means "to reduce someone to the role of an object, a tool", with the second meaning being "to provide something with a real shape". ${ }^{14}$ What is important for me as a researcher, is an attempt at understanding, explaining both the issue

12 J. Puzinina, O pojęciu manipulacji, [in:] Nowomowa, ed. by J. Rokoszowa, „Zeszyty Edukacji Narodowej”, Londyn 1985, p. 7.

13 The on-line Oxford Learner's Dictionary defines objectification as the act of treating people as if they are objects, without rights or feelings of their own [translator's note].

14 PWN Dictionary of the Polish Language, <https://sjp.pwn.pl/slowniki/ uprzedmiotowienie.html> 2019.04.23. 
itself, naming it, but also getting to know it and explaining the causes/ process/ progress of the phenomenon. This is important for me for reasons of better understanding, to suggest, better activity leading to social inclusion of the discussed group of people. ${ }^{15}$

Objectification is the lack of one's capacity to become aware of the fact of being subjected to changes and influence on these thanks to own more or less autonomous activity. An individual is somebody with a specific identity that discerns them from others; their own activity depends to a great extent on themselves. Objectification in turn is the removal of the capacity of an individual to become aware of the fact of being subjected to changes and the influence on these by their own more or less autonomous actions; a lack of their own identity taking into account individuality, the biological and life age. Objectification can be described as:

- primarily: lack of capacity to recognise one's own objective situation and to understand its individual components (category of seeming),

- secondly: lack of capacity to interpret and select inflowing stimuli due to the set task (category of power),

- thirdly: lack of internal organisation of the individual coupled with their limited position in the world, lack of bonds between them and their environment and the influence exerted upon them by their own activity (marginalisation of activity - exclusion).

The etymology of the concept indicates objective treatment of the person being manipulated. The removal of objectivity from the individual being manipulated gives rise to consequences reaching

15 Note on action research: "Action research is defined, as a research approach, by practicality, purposefulness, periodicity, collaboration, future orientation, situation orientation, transformation. In this context it is worth noting that, as stated by Andrew Brown and Paul Dowling, action research is a concept used for projects, in which practitioners seek efficient transformation in their own practical work"; I quote from: Maria Szymańska, Badania w działaniu, [in:] (ed. by) M. Ciechowska, M. Szymańska, Wybrane metody jakościowe w badaniach pedagogicznych część 1, Wydawnictwo Naukowe Akademii Ignatianium w Krakowie, Kraków 2018, pp. 234-235. 
into the area of their freedom. This is a reduction of the space available for their free choice. The excess reduction of freedom is entering the area of manipulation. The person being manipulated wrongly believes that they are in control of their activity. They are not aware that they are merely a tool at the hands of an actual perpetrator, only serving the achievement of objectives of importance for them. ${ }^{16}$ The effect of manipulation is objectification of persons with deeper and deep intellectual disability. On the basis of the mentioned activity, categories were derived that are presented in the present article: of seeming, power and marginalisation of activity - exclusion.

\section{Methodology and concept of own research}

The objective of the article is the presentation of effects of activities experienced by adults with deeper and deep intellectual disability while inhabiting a social nursing home - the objectification of their adulthood. In the discussed case, the objectification is the effect of simplified trust that contributes to manipulation. The basic assessed group - the core of the conducted research - are female inhabitants of a nursing home ${ }^{17}$ and persons in contact with them in the common space.

The utilised method of so-called action research is defined, as a research approach, by practicality, purposefulness, periodicity, collaboration, future orientation, situation orientation, transformation. ${ }^{18}$ In this context it is worth noting that, as stated by Andrew

16 A. Wróbel, Wychowanie a manipulacja, Oficyna Wydawnicza „Impuls”, Kraków 2006, p. 18.

17 A social nursing home for children and youths with intellectual disability is operated by an order in one of the counties of the Silesian voivodeship in Poland. There are 89 residents in total, 59 with deep intellectual disability, 22 with deeper intellectual disability and wight with minor intellectual disability. The majority are elderly persons, there are only thirty residents under the age of 25 , and they participate in education, re-validation or rehabilitation classes at a special school.

18 See R. Phelps, S. Hase, Complexity and action research: exploring the theoretical and methodological connections, op. cit.; P. Jarvinen, Action research as an approach in 
Brown and Paul Dowling, action research is a concept used for projects, in which practitioners seek efficient transformation in their own practical work. ${ }^{19}$

The research material used in the present study constitutes personal experiences gained during work with persons with deeper and deep intellectual disability, their caretakers, parents and other specialists working with them, gained through participation in various activities/ projects aimed at them. Free, narrative discussions as well as focused discussions were conducted with representatives of the indicated groups (save for persons with deep, and in certain cases, significant intellectual disability). The analysis of the research material was conducted according to the action research methodology. ${ }^{20}$

During regular observations as part of action research, I experience as a participating researcher certain activities that refer to the objectification of persons with intellectual disability; I also witness situations related to processes of manipulation of the discussed group.

The study shall present categories of objectification derived from action research and the category of manipulation. ${ }^{21}$ Depending on

design science, op. cit.; M. Szymańska, Transformative creativity in teacher formation: a pedagoggical approach, op. cit. Quoted from Maria Szymańska, Badania w działaniu, [in:] (ed. by) M. Ciechowska, M. Szymańska, Wybrane metody jakościowe w badaniach pedagogicznych część 1, Wydawnictwo Naukowe Akademii Ignatianium w Krakowie, Kraków 2018, p. 234.

19 A. Brown, P. Dowling, Doing research/freading research: A mode of interrogation for teaching. Routledge Falmer, London 2001, p. 152. Quoted from: Maria Szymańska, Badania w działaniu, [in:] (ed. by) M. Ciechowska, M. Szymańska, Wybrane metody jakościowe w badaniach pedagogicznych część 1, Wydawnictwo Naukowe Akademii Ignatianium w Krakowie, Kraków 2018, pp. 234-235.

${ }^{20}$ During the construction of the research, the spiral model of research phases in action research was used, entailing common reflection on observation results to identify the research problem, through planning and implementation of activity, concluded with renewed reflection and the planning of further research; quoted from: Kurt Lewin „Badania w działaniu a problemy mniejszości, [in:] (ed.) H. Cervinkova; B.D. Gołębniak, Badania w działaniu: Pedagogika i antropologia zaangażowane, Wydawnictwo Naukowe DSW. Wrocław 2010, pp. 5-18.

${ }^{21}$ A. Wróbel, citing M. Karwat, lists three examples of objectification. The first is using somebody as a tool of their activity, at the same time excluding them from 
the assumed interpretation formula, they can take on the following forms:

- linear, when they emerge as a relationship of results, e.g. infantilisation, learned helplessness or "territoriality" or seeming, power and marginalisation of actions/ exclusion (this shall be discussed in more detail in course of the article), etc.

- metaphorical - e.g. verbal - related to activity, or nominal - related to the status/ condition.

- "a complex map construct" - the established category frequently leads to something or stems from something, remaining in coordination, subordination, superordination with other categories.

The categories referred to below were derived from the action research. On their basis, and on the basis of their mutual relationship, a theoretical construct is established that reflects reality. The linear version is used in the current article.

I identified in course of action research the following categories of objectification, as the effects and results of infantilisaton of adults with deeper and deep intellectual disability:

- infantilisation ...

- "learned helplessness"...

- territoriality - range ...

- "piece of furniture" ...

- (un)recognised adulthood ...

- "activation of adulthood"...

- marginalisation of activity/ exclusion...

- power ...

- seeming ...

The proposed categories make up the daily reality of the indicated group of people. At the same time, they lead to rejection of

activity, marginalising it. Second: If leaders at a certain level make decisions in the name of the entire organisation. Third: Intervening in people's consciousness and influencing their attitudes and behaviour using their own consciousness, conf. A. Wróbel, Wychowanie a manipulacja, Oficyna Wydawnicza „Impuls”, Kraków 2006, pp. 38-39. 
recognition of their adulthood. As a consequence, this leads to a reduced reality. .22

Due to the unconstructive character of the utilised research techniques, and the broader scope of the conducted research, exceeding the issues described in the present article, the analysed notions were very diverse, however, concentrated around the fundamental research problem of objectification of adulthood of persons with deeper and deep intellectual disability. Hence, the presented study shall describe three examples of objectification that are linear in form, hence, they originate from each other linearly. The listed systems may take on diverse arrangements, depending on the time, place or position of the researcher. ${ }^{23}$

As was already stated, certain actions cause the emergence of others or arise from them.

\section{The category of seeming}

The first situation, in which adults with deeper and deep intellectual disability experience objectification, is activity being seeming. As a result of their limitations, one can see in them the lack of ability to recognise their objective situation and to understand its individual components. "Society", meaning, fully able persons, is eager to show how the qualify of life of persons with deeper and deep intellectual disability changed. They can participate in regular activities adapted to their capacities. Government entities and

22 "Reduced reality is reality that refers to specific social situations, in particular those, in which for some reasons somebody or something deliberately or unconsciously reduces or experiences an overly narrow, limited, hence, reduced role. Something paralysing, deforming a person's feelings, relations, capacities, capabilities. It hinders, sometimes even prevents, development in line with the expectations of the individual and/or reality"; quoted from: D. Prysak, Zredukowana dorostość osób głębiej niepetnosprawnych intelektualnie, „Wychowanie Na Co Dzień”, no. 4(253), 2015, p. 27.

${ }^{23}$ Z. Gajdzica, O pozycji badacza w poznawaniu świata osób niepetnosprawnych, Przegląd Badań Edukacyjnych, no. 18 (1/2014), pp. 103-114. 
NGOs offering broadly understood aid (from early support to vocational training) are mostly adapted to the discussed group. During daily activities, they feel, to a certain extent, equal to their peers. For many of their caretakers and parents, this is quite a lot of aid and support. They are very frequently presented as joyous and cheerful. "Within social space, one can also see activities entailing the integration in people's consciousness and the influence on their attitudes and behaviour via their own consciousness. However, the basis of control in this case is subversion, tricking of the recipient, etc. Hence, this is higher-order social manipulation, based on indirect objectification, which may use a facade of expression of respect towards the subjectivity of another, as in the case of flattery $(\ldots)^{\prime \prime} .24$ They are treated as other citizens of our country.

However, this beautiful reality actually ends, in case of both discussed groups, at the stage of education. After this period, they are actually left to be dependent on their parents, caretakers, and the passion of their teachers who do not agree for years of their work with them to be wasted. The seeming of actions may be noted as present in financial aid as well. The family of a person with deeper and deep intellectual disability is eligible for all kinds of financial support in the form of benefits and aids for specialised equipment. The average citizen rarely considers, whether the amounts proposed by the state are sufficient. What kind of consequences can it have on us as a society? What happens, what is the fate of those adults, when their next of kin are gone? Who then actually cares for persons with deeper and deep intellectual disability? This is an example of "impression management" 25 by persons on whom the indicated group is dependent to a certain extent. This stems from the actual lack of capacity to check, or rather even to verify, whether the conveyed information are in line with the expectations of the interested individuals.

24 A. Wróbel, Wychowanie a manipulacja, Oficyna Wydawnicza „Impuls”, Kraków 2006, p. 39.

${ }^{25}$ R. Keyes, Czas prawdy, Nieszczerość i oszustwa w codziennym życiu, Wydawnictwo PWN, Warszawa 2018, p. 62. 


\section{The category of power}

The other situation, in which persons with deeper and deep intellectual ability experience objectification, refers to "power". A particular type of objectification in manipulation is the case when the powers on a certain level make decisions in name of the entire organisation, without discussing with lowest-rank members:

"Regrettably, there are too few therapeutic day care centres for our already - graduates, who attended our classes. It is sad to see them later in the street so sad, down, because all they are left with it sitting at home". ${ }^{26}$

The described group of people is characterised by the lack of capacity to interpret and select incoming stimuli on the basis of set tasks, which makes it difficult for them to understand decisions or actions of others. Such social manipulation ceases to influence attitudes and behaviour of people, and just becomes a form of activity of $X$ (or of many $X$ ) undertaken by them in their own name and in the name of $Y$ (or of many $Y$ ) without the knowledge of $Y$ (of many $Y$ ). This is activity that is characterised by fraud, and exhibits objective treatment of people. These are significant factors of highest importance for the entire concept of manipulation of people in all its forms. The example given describes situations of influence on people and deciding about their fate without consideration for them, as if they were items, objects. This is objectification of people - of individuals, groups, communities (...) based on force, or on a feeling of superiority and impunity allowing the omission of human subjectivity. Utilisation of such a method of governance, management or leadership, is related to direct and almost literal objectification of one's subjects' 27 :

26 Statement by specialist in oligophrenopaedagogy with 29 years of work experience with persons with deep intellectual disability.

27 Conf. A. Wróbel, Wychowanie a manipulacja, Oficyna Wydawnicza „Impuls”, Kraków 2016, p. 38. 
"It would be good, if the government planned and included in some legal acts fixed financing e.g. for therapeutic day care centres for adults with deep intellectual disability, and right now we live in constant fear whether our project qualifies for financing. We go on from project to project like this. Sadly, we do not always get money for our activities and maintaining the day care centre itself" ${ }^{28}$

Frequently in our daily lives we see that the example comes from above. Suddenly, recent times have shown what power can do; sadly, it was not advantageous for people with intellectual disability. An example can be the the May 2018 protest in the Polish Sejm:

"The needs are enormous; this is reported by both the disabled and their parents; what does it matter if we even built such a round-theclock care centre for our former attendees, the money would be there, parents want to give money, too, if it does not succeed. The state cannot be counted on for aid and help. In truth, everything goes to children, the most is provided for them, and the adults and elderly disabled are left to be forgotten; sad, isn't it?". ${ }^{29}$

Signs of marginalisation and exclusion of disabled persons are visible both on the personal, institutional, cultural as well as the social level, and they are an indication of discrimination against this group. Discrimination against the disabled may be referred to as a sort of social repression that has its source in the conviction that the disabled must be made to submit due to their disability. ${ }^{30}$

\section{Marginalisation of activity - exclusion}

A result of the two examples of objectification named earlier is the "marginalisation of activity", leading in consequence to the

28 Statement by general manager of an NGO from the Cieszyn county in the Silesian Voivodeship, with 25 years of professional experience.

29 Statement by general manager of an NGO with 35 years of professional experience.

${ }^{30}$ B. Colin, Mercer Geod, Niepetnosprawność, Wydawnictwo Sic!, Warszawa 2008, p. 29. 
exclusion of the group. Mirosław Karwat concludes that "both a person subjected to open, clear influence, for instance, due to persuasion, as well as the victim of indirect or direct compulsion can become tools used to achieve the objectives of others. He also believes that own own profit may be achieved not only using someone as a tool of one's own activity, but also by way of excluding them from activity, marginalising their work or involving them in something else". ${ }^{31}$ Hence, in characterising manipulation, it is better to speak of objectification of others than of instrumentalisation.

“(..) we always wait for invitations, because we go where we are invited; we always wait for these two invitations, because only you invite us". 32

The quoted statement confirms, how the discussed group may be consciously or unconsciously excluded from daily activities aimed at society in general. The low number of suggested concrete activities leads to systematic removal of the social group that is made up of persons with deeper and deep intellectual activity from the main stream of daily life, and is also related to the disadvantageous financial situation, exclusion from the subdivision of work, institutional segregation and deprivation of civil rights. ${ }^{33}$

The lack of concrete proposals of activity for adults with deeper and deep intellectual disability makes them participate less and less in daily life. If they do not participate, then others get used to their absence from common space. They do not see their daily issues, the difficulties they experience, their needs. Unheard are their voices, but also the voices of their caretakers, parents, specialists. In reality, they do not have the right to indicate their needs. This take place very gently, it is veiled. One could say that they are sill there, but

31 A. Wróbel, Wychowanie a manipulacja, Oficyna Wydawnicza „Impuls”, Kraków 2016, p. 39.

${ }^{32}$ Statement by specialist in oligophrenopaedagogy with 20 years of work experience with persons with deep intellectual disability.

${ }_{33}$ B. Colin, Mercer Geod, Niepetnosprawność, Wydawnictwo Sic!, Warszawa 2008, p. 30. 
somewhat invisible. One does not need to be directly told that they are unwelcome, due to their looks, behaviour, lack of communication, even uselessness ${ }^{34}$ :

(...) after all, they won't contribute to the GDP (gross domestic product)

All it takes is to omit them, failing to invite them to common activity in social life. The lack of fixed options and financing by the legislator of e.g. therapeutic day care centres, a larger number of occupational therapy workshops or other solutions causes the slow reduction of their participation in daily lives. Instead of including them in life by integration of fully able and disabled persons, we gradually exclude them. Showing, supporting work aimed only at a certain age group, e.g. little children, we unconsciously or consciously exclude the adulthood of these people. Failing to note at early stages of education that these children will one day grow up, we in actuality do not educate society about themselves.

It is easier to be charmed by children who even have compounded intellectual disabilities. But when we face the same person when they are grown up, we sometimes experience fear, shock, even abhorrence:

such people scare me; when I saw them so close, I feared that they might do something to me; they said something, but I didn't understand. I definitely prefer little children (...).35

\section{Conclusion}

Considering the context of the conducted action research, the above description constitutes a sort of reflection on daily practices in meeting adults with deeper and deep intellectual disability. They are thoughts both about their future, described solely by stays in

34 Statement by local government member from the county of Cieszyn of 2018.10.21.

35 Statement by full-time first-degree female student, 2019.01.28. 
social nursing homes after their next of kin are gone, as well as our future as society that will care for the described group. As a result, the following questions emerge: First of all, will we be able to maintain their quality of life that the legislator-dreamer described? Second of all, considering the estimates of professional stratification of labour, will such work be undertaken by future graduates of paedagogical studies as their professional lives related to the mentioned group? I am aware that there are more questions, and that they will keep coming back. The problematisation, the description of this reality is but a vantage point for activity that will contribute to further scientific research.

\section{Bibliography}

[1] Borzyszkowska H., Upośledzenie -rewalidacja dzieci i młodzieży upośledzonych umystowo, [in:] Encyklopedia pedagogiczna, ed. by W. Pomykało, Warszawa 1993, p. 885.

[2] Barnes Colin, Mercer Geod, Niepetnosprawność, Wydawnictwo Sic!, Warszawa 2008.

[3] Czerepaniak-Walczak M., Badanie $w$ działaniu $w$ kształceniu $i$ doskonaleniu nauczycieli, „Przegląd badań Edukacyjnych” 2014, no. 2.

[4] Doliński D., Inni ludzie w procesach motywacyjnych, [in:] Psychologia. Podręcznik akademicki, vol. 2, ed. by J. Strelau, GWP, Gdańsk 2000.

[5] Gajdzica Z., O pozycji badacza w poznawaniu świata osób niepetnosprawnych, „Przegląd Badań Edukacyjnych”, no. 18 (1/2014).

[6] Gołębniak B.D., Edukacyjne badania w działaniu - między akademicka legitymizacją a realizowanymi uproszczeniami, [in:] H. Cervinkova, B.D. Gołębniak (ed.) Edukacyjne badania w działaniu, Wydawnictwo Naukowe Scholar, Warszawa 2013.

[7] Grzywa A., Potęa manipulacji, Wydawnictwo Czelej, Lublin 2012.

[8] Prysak D., Zredukowana dorosłość osób głęiej niepetnosprawnych intelektualnie, „Wychowanie Na Co Dzień", no. 4(253), 2015.

[9] Keyes R., Czas prawdy, Nieszczerość i oszustwa w codziennym życiu, Wydawnictwo PWN, Warszawa 2018.

[10] Lepa A., Świat manipulacji, Wydawnictwo Tygodnika Katolickiego „Niedziela”, Częstochowa 1994.

[11] Lewin K., Badania w działaniu a problemy mniejszości, [in:] (ed.) H. Cervinkova, B.D. Gołębniak, Badania w dziataniu: Pedagogika i antropologia zaangażowane, Wydawnictwo Naukowe DSW, Wrocław 2010. 
[12] Reason P., Torbert W.R., Zwrot dziataniowy. Ku transformacyjnej nauce społecznej, [in:] H. Cervinkova, B.D. Gołębniak (ed.) Badania w działaniu. Pedagogika i pedagogika zaangażowane, Wydawnictwo Naukowe Dolnośląskiej Szkoły Wyższej, Wrocław 2010.

[13] Mrugalska K. (ed.), Osoby upośledzone fizycznie lub umystowo, Warszawa 1996.

[14] Nawrat R., Czy można manipulować przechodniami na polskiej ulicy? Empiryczne badanie efektywności wybranych sekwencyjnych procedur zwiększania uległości, „Przegląd Psychologiczny" 1989, vol. XXXII, no. 1.

[15] Puzinina J., O pojęciu manipulacji, [in:] Nowomowa, ed. by J. Rokoszowa, „Zeszyty Edukacji Narodowej", Londyn 1985.

[16] Szymańska M., Badania w działaniu, [in:] (ed. by) M. Ciechowska, M. Szymańska, Wybrane metody jakościowe w badaniach pedagogicznych część 1, Wydawnictwo Naukowe Akademii Ignatianium w Krakowie, Kraków, 2018.

[17] Ziembiński Z., Wychowanie a manipulacja, „Wykłady Inauguracyjne” no. 21, Wydawnictwo Naukowe UAM, Poznań 1981.

[18] PWN Dictionary of the Polish Language, https://sjp.pwn.pl/slowniki/uprzed miotowienie.html 2019.04.23.

[19] Wróbel A., Wychowanie a manipulacja, Wydawnictwo Impuls, Kraków 2006. 